\title{
Quantifying the short-term temperature effect on light-saturated photosynthesis of intertidal microphytobenthos
}

\author{
G. F. Blanchard ${ }^{1, *}$, J.-M. Guarini ${ }^{1}$, P. Richard ${ }^{1}$, Ph. Gros ${ }^{2}$, F. Mornet ${ }^{1}$

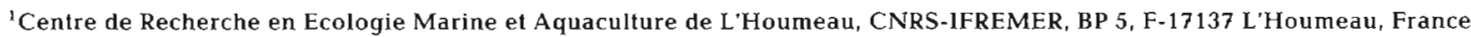 \\ ${ }^{2}$ IFREMER Centre de Brest, BP 70, F-29280 Plouzané, France
}

\begin{abstract}
A mathematical expression is proposed to describe the relationship between the photosynthetic capacity $\left(P_{\text {max }}\right)$ of natural assemblages of motile benthic diatoms and temperature. Experiments were performed in 2 different seasons to document the response of $P_{\max }$ to a rapid increase in temperature $\left(3^{\circ} \mathrm{C} \mathrm{h}^{-1}\right)$. In both cases, there was a progressive increase in $P_{\max }$ up to an optimum temperature $\left(T_{\text {opt }}\right.$ ), beyond which $P_{\max }$ declined rapidly. $T_{\text {opt }}$ did not change from September to December 1995, but the maximum photosynthetic capacity $\left(P_{\text {MAXX }}\right.$ i.e. $P_{\max }$ at $\left.T_{\text {opt }}\right)$ was twice as high in September as in December
\end{abstract}

KEY WORDS: Microphytobenthos - Temperature - Intertidal Photosynthetic capacity $\cdot$ Model

Due to the combination of seasons, tidal cycle and weather conditions, intertidal mudflats are subject to large temperature changes during low tides (Harrison 1985, Harrison \& Phizacklea 1985, 1987). The surface mud is usually inhabited by a dense community of benthic microalgae (Colijn \& de Jonge 1984) in the top few cm (de Jonge \& Colijn 1994, Cariou-Le Gall \& Blanchard 1995), but the photosynthetic activity is restricted to only the top $\mathrm{mm}$ - where temperature changes occur most rapidly and intensely - because of a strong light attenuation in fine sediments (Haardt \& Nielsen 1980, Jørgensen \& Des Marais 1986).

Temperature has been shown to have a significant effect on primary production and growth rates of microphytobenthos not only at a seasonal scale (Cadée \& Hegeman 1974, Admiraal \& Peletier 1980) but also at an hourly scale (Colijn \& van Buurt 1975, Admiraal 1977) during the emersion periods on intertidal mudflats (Rasmussen et al. 1983). This short-term effect is different from one species to another (Admiraal 1977), and acclimation seems to occur during the

\footnotetext{
•E-mail: gblancha@rochel.ifremer.fr
}

seasonal cycle (Rasmussen et al. 1983, Grant 1986). Although important, these results have not yet been formalized by a mathematical expression describing the physiological response of benthic microalgae to temperature. The temperature model that has been employed so far is Eppley's (1972) equation. This equation, however, gives the variation in maximum expected growth rate of phytoplankton with temperature (based on a literature review), and not the actual photosynthetic response of microphytobenthos to short-term changes in temperature.

The present note aims therefore at proposing a mathematical equation describing the relationship between the photosynthetic capacity of natural assemblages of benthic diatoms and temperature to be used in a model of benthic primary production. As we were primarily interested in the kinetic aspect of the relationship, we measured experimentally the response of the photosynthetic capacity to a rapid increase in temperature, similar to what occurs in the field at low tide, in 2 different seasons.

Material and methods. Light-saturated photosynthetic rates were measured on isolated motile benthic diatoms separated from intertidal mud of the temperate Bay of Marennes-Oléron along the French Atlantic coast (Charente-Maritime, France). The sediment was sampled at low tide on the mudflat on 2 different dates: 11 September and 11 December 1995. All measurements were performed within $48 \mathrm{~h}$. Temperature of the surficial sediment (top $1 \mathrm{~mm}$ ) ranged from 16.4 to $24.6^{\circ} \mathrm{C}$ when exposed to the air during low tide for the period 12 to 17 September 1995 , and from 1.0 to $10.5^{\circ} \mathrm{C}$ for the period 5 to 11 December 1995 (Fig. 1).

Separation of microalgae from the sediment: Ben thic diatoms were separated from the mud using Couch's (1989) method with slight modifications. This method is based on the properties of vertical migration 


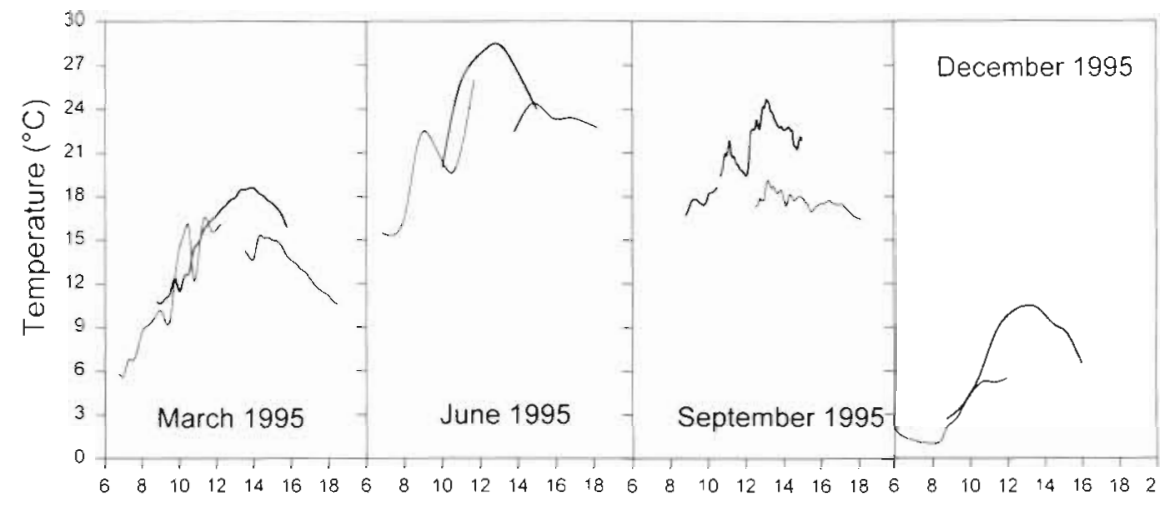

Universal Time (h)
Fig. 1. Temperature recordings at the surface of the mud (top $1 \mathrm{~mm}$ ) in March, June, September and December 1995 at different times of the tidal cycle: when low tide occurred at 09:00, at 12:00 and 15:00 h UT. Temperature was recorded continuously using a Li-Cor temperature sensor (1000-15 soil temperature sensor) connected to a Ll-1000 dataLogger of motile microalgae. The collected mud was spread on flat trays to a depth of about $1 \mathrm{~cm}$. A nylon screen (63 $\mu \mathrm{m}$ mesh) was laid upon the sediment surface and covered with a 4 to $5 \mathrm{~mm}$ layer of combusted silica powder $(60$ to $210 \mu \mathrm{m})$. The trays were held under light and the silica powder was kept wet by spraying with GF/F filtered seawater from the sampling site (salinity $=36 \%$ ). Within 1 to $3 \mathrm{~h}$, the silica powder, into which the motile microalgae had migrated, was gently taken up by scraping, and sieved under a thorough rinsing with seawater through a $63 \mu \mathrm{m}$ screen to separate the diatoms from the greater part of the silica powder and from any nematodes which might have also migrated into the silica powder. On both dates, benthic diatoms were identified and enumerated.

Experimental design: The suspension of isolated benthic diatoms was gently homogenized with a magnetic stirrer, and $60 \mathrm{ml}$ subsamples were withdrawn for further incubation at different temperatures (salinity = $36 \%$ ). An experiment was designed to assess the shortterm response of the photosynthetic capacity $\left(P_{\max }\right)$ to an increase of temperature over the range 5 to $35^{\circ} \mathrm{C}$ (with a $3^{\circ} \mathrm{C}$ step, i.e. 11 temperatures were tested), this range being representative of the temperature changes $\left(3\right.$ to $\left.33^{\circ} \mathrm{C}\right)$ measured at the surface of the mud during low tide over an $18 \mathrm{mo}$ period (G. Blanchard unpubl.).

The subsamples were placed in a temperature-controlled chamber under light-saturating conditions. Temperature was progressively lowered down to $5^{\circ} \mathrm{C}$. $\left(P_{\max }\right)$ was measured on 1 of the subsamples and temperature was then raised by $3^{\circ} \mathrm{C}$; each increase was followed by an equilibrium period of $1 \mathrm{hr}$. The same procedure was repeated up to $35^{\circ} \mathrm{C}$. The rate of temperature increase $\left(3^{\circ} \mathrm{C} \mathrm{h}^{-1}\right)$ was chosen to be comparable to that which occurs at the surface of the mud (Fig. 1), and to be in the range $\left(2\right.$ to $\left.4^{\circ} \mathrm{Ch}^{-1}\right)$ of published data concerning temperature changes of intertidal mud (Harrison 1985).
Measurement of light-saturated photosynthesis: The $P_{\max }$ corresponding to the light-saturated part of the photosynthesis-irradiance relationship was estimated using a photosynthetron (Lewis \& Smith 1983) which allows simultaneous measurements of the photosynthetic rate at different light levels. For the present experiment only light levels in the range 1000 to $1600 \mu \mathrm{mol} \mathrm{m} \mathrm{m}^{-2} \mathrm{~s}^{-1}$ were considered for calculation of $P_{\max }$. Photoinhibition at the highest light levels was never observed.

For each temperature, ${ }^{14} \mathrm{C}$-bicarbonate $(45$ to $60 \mathrm{mCi} \mathrm{mmol}^{-1}$ stock solution) was added to 1 subsample to reach a final concentration of about $0.4 \mu \mathrm{Ci} \mathrm{ml} l^{-1}$. Aliquots ( $1 \mathrm{ml}$ ) were then dispensed into $20 \mathrm{ml}$ scintillation vials and incubated for $20 \mathrm{~min}$ at the chosen temperature. Dark and formalin controls were also incubated. After incubation, all biological activity was stopped by the addition of $50 \mu$ l of buffered formalin. The excess radioactivity was removed by adding $250 \mu \mathrm{l}$ of $6 \mathrm{~N} \mathrm{HCl}$ and shaking for $2 \mathrm{~h}$. A $10 \mathrm{ml}$ volume of Instagel (Packard) was introduced into each vial and dpm (disintegrations per minute) were counted in a Packard Tri-Carb 1500 Liquid Scintillation Analyser including quenching correction. All photosynthetic rates were normalized to chl a which was measured fluorometrically on $5 \mathrm{ml}$ triplicates subsampled before the addition of radioactivity. Total carbon dioxide of the water was previously estimated by determination of carbonate alkalinity (Parsons et al. 1984).

Results and discussion. The short-term response of $P_{\max }$ to a rapid increase in temperature is shown in Fig. 2. The shape of the relationship between $P_{\max }$ and temperature is typical of short-term temperature effects on light-saturated photosynthesis (see Davison 1991 for a review): there is a progressive increase of $P_{\text {max }}$ with increasing temperature up to an optimum temperature, beyond which $P_{\max }$ declines rapidly.

The following non-linear model was fitted to our experimental data (Fig. 2): 


$$
P_{\max }(T)=P_{\mathrm{MAx}}\left(\frac{T_{\max }-T}{T_{\max }-T_{\mathrm{op} t}}\right)^{\beta} \exp \left[-\beta\left(\frac{T_{\mathrm{max}}-T}{T_{\max }-T_{\mathrm{opt}}}-1\right)\right]
$$

with $T \leq T_{\max }$ and $T_{\text {opt }}<T_{\max }$. Eq. (1) describes the variation of the photosynthetic capacity $P_{\max }[\mu \mathrm{g} \mathrm{C}(\mu \mathrm{g}$ chl a $)^{-1} \mathrm{~h}^{-1}$ ] as a function of temperature $T\left({ }^{\circ} \mathrm{C}\right)$. The notation used makes the physiological significance of the 3 parameters, $T_{\max ,} T_{\mathrm{opt}}$ and $P_{\mathrm{MAX}}$, self-evident \{notice that $\left.P_{\text {MAX }}=\operatorname{Sup}\left[P_{\operatorname{mix}}(T)\right]=P_{\max }\left(T_{\text {opl }}\right)\right\}$. The role of the fourth parameter $\beta$ (dimensionless) is easier to understand when Eq. (1) is written in a rescaled form:

$$
\text { let } Y=\frac{P_{\max }(T)}{P_{\text {MAX }}}, \quad \theta=\left(\frac{T_{\max }-T}{T_{\max }-T_{\text {opt }}}\right)
$$

The relationship between the relative rates of variation of the dimensionless variates $Y$ and $\theta$ is then:

$$
\frac{\mathrm{d} Y}{Y}=\beta(1-\theta) \frac{\mathrm{d} \theta}{\theta}, \quad \theta>0
$$

Thus, the parameter $\beta$ contributes to the sensitivity of $\mathrm{d} Y / Y$ to a variation in $\mathrm{d} \theta / \theta$. The influence of $\beta$ is all the more effective since $\theta$ differs from 1 (that is, $T$ is distant from $T_{\text {opt }}$ ).

The 4 parameters of Eq. (1) were identified by minimization of the ordinary least-squares criterion, using a direct search method (Simplex of Nelder \& Mead 1965). The mean square error (MSE) matrix was chosen as a measure of accuracy of the estimates. The MSE matrix has been computed by resampling the centered residuals, according to the bootstrap method (Efron 1979) applied in the context of regression (see for example Efron 1988)

$P_{\text {Max }}$ (the maximum value of $P_{\max }$ ) was almost twice as high in September $\left[5.81 \pm 0.15 \mu \mathrm{g} \mathrm{C}(\mu \mathrm{g} \mathrm{chl} \mathrm{a})^{-1} \mathrm{~h}^{-1}\right]$

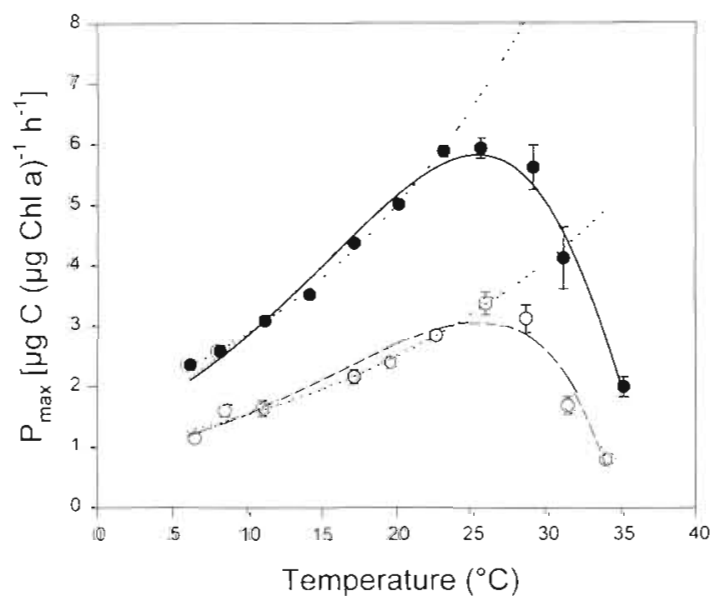

Fig. 2. Relationship between $P_{\max }$ and temperature. September 1995: (๑) experimental data ( \pm experimental SE) $(-)$ fitted curve. December 1995: (0) experimental data ( \pm experimental SE): (---) fitted curve. (...) Eppley's equation for each data set

\begin{tabular}{|c|c|c|c|c|}
\hline & \multicolumn{2}{|c|}{ September 1995} & \multicolumn{2}{|c|}{ December 1995} \\
\hline & Estimate & MSE & Estimate & MSE \\
\hline $\begin{array}{l}P_{M A X} \\
\quad \mu g C(\mu g c h l d)^{-1} h^{-1}\end{array}$ & 5.81 & 0.15 & 3,04 & 0.16 \\
\hline$T_{\max 1}{ }^{\circ} \mathrm{C}$ & 38.2 & 1.55 & 34.9 & 0.96 \\
\hline$T_{(1, p),},{ }^{\circ} \mathrm{C}$ & 253 & 0.52 & 25.4 & 0.86 \\
\hline$\beta$, dimensionless & 1.76 & 0.56 & 1.03 & 0.42 \\
\hline
\end{tabular}

Table 1. Estimates of the parameter values of Eq. (1) as well as their mean square error (MSE)

as in December [3.04 $\left.\pm 0.16 \mu \mathrm{g} \mathrm{C}(\mu \mathrm{g} \text { chl a })^{-1} \mathrm{~h}^{-1}\right]$, whereas $T_{\mathrm{opt}}$ did not change $(25.29 \pm 0.52$ and $25.38 \pm$ $0.86^{\circ} \mathrm{C}$, respectively) (Table 1, Fig. 2). So, there appears to be a seasonal effect on the hourly response of microphytobenthos to a rapid increase in temperature. This might be due partly to a change in the community structure of motile benthic diatoms: in September, the community was completely dominated by Navicula spp. (>98\%) whereas in December Pleurosigma spp. reached about $22 \%$ of the community and Navicula spp. only $53 \%$.

The seasonal effect could also be due to a physiological acclimation, so that the combination of both taxonomical and physiological changes makes it necessary to establish the relationship between $P_{\max }$ and temperature at each season. Indeed, one has to check whether $T_{\text {opt }}$ changes during the seasonal cycle or not because, based on our measurements in September and December, the temperature recordings for June (Fig. 1) show potentially inhibitory temperatures (those above $25^{\circ} \mathrm{C}$ )

Colijn \& van Buurt (1975) found a similar relationship between photosynthesis and temperature in sediments from the Dutch Wadden Sea, but the maximum photosynthetic capacity occurred between 20 and $22^{\circ} \mathrm{C}$ and was lower than $1 \mu \mathrm{g} \mathrm{C}(\mu \mathrm{g} \mathrm{chl} a)^{-1} \mathrm{~h}^{-1}$. This may be due to the fact that measurements were made on intact sediment so that the photosynthetic rate was divided by too large an amount of non-photosynthetically active chl a. Admiraal (1977) also found the same kind of relationship between the growth rate (doubling per day) of single diatom species and temperature. Concerning the seasonal effect, Rasmussen et al. (1983), in the Danish Wadden Sea, found both a change in the maximum photosynthetic capacity and the optimal temperature, thus resulting in either almost symmetrical bell-shaped curves or a linear relationship in the range 5 to $30^{\circ} \mathrm{C}$. The maximum photosynthetic capacity was similar to our findings for comparable periods [about $4 \mu \mathrm{g} \mathrm{C}(\mu \mathrm{g} \mathrm{chl} \mathrm{a})^{-1} \mathrm{~h}^{-1}$ at $30^{\circ} \mathrm{C}$ in September].

Based on our data, Eppley's (1972) equation may be used as a rather good predictor of $P_{\text {max }}$ in the range of 
temperature lower than $T_{\mathrm{opt}}$ (Fig. 2). However, it has several drawbacks

(1) Eppley's equation is inappropriate for ecophysiological purposes because it does not take into account $T_{\text {opt }}$ in its formulation, and because it cannot fit $P_{\max }$ at $T_{\text {opt }}$ nor the steep decrease of $P_{\max }$ above $T_{\text {opt }}$. It is nevertheless used in models when temperature is integrated over the day (Raillard \& Menesguen 1994).

(2) Eppley's equation implies a constant $Q_{10}(=1.88)$ whereas $Q_{10}$ analytically calculated from Eq. (1):

$$
\begin{aligned}
Q_{10} & =\frac{P_{\max }(T)}{P_{\max }(T-10)} \\
& =\exp \left\{\beta\left[\ln \left(\frac{T_{\max }-T}{T_{\max }-T+10}\right)\right]+\frac{10}{T_{\max }-T_{\text {opt }}}\right\} \\
& \text { defined for } T<T_{\max }
\end{aligned}
$$

shows instead a decrease from low temperatures up to $T_{\max }$ (Fig. 3). Such results have already been observed by Palmisano et al. (1987) and Arrigo \& Sullivan (1992) for sea ice microalgae, but there has been no report concerning microphytobenthos.

From a kinetic standpoint, our experimental results show a rapid response of $P_{\max }$ to an increase in temperature at a rate of $3^{\circ} \mathrm{C} \mathrm{h}^{-1}$. If we extrapolate this to field conditions, for example in September (Fig. 1) when temperature increased from about $16^{\circ} \mathrm{C}$ to about $25^{\circ} \mathrm{C}$ during low tide, $P_{\max }$ could potentially increase by about $40 \%$ (Fig. 2). This enhanced productivity could be realized at the surface of the sediment where motile microalgae migrate at low tide and are exposed to saturating light conditions, provided there is no nutrient limitation. Our results thus clearly indicate that temperature can exert a tight control on benthic photosyn-

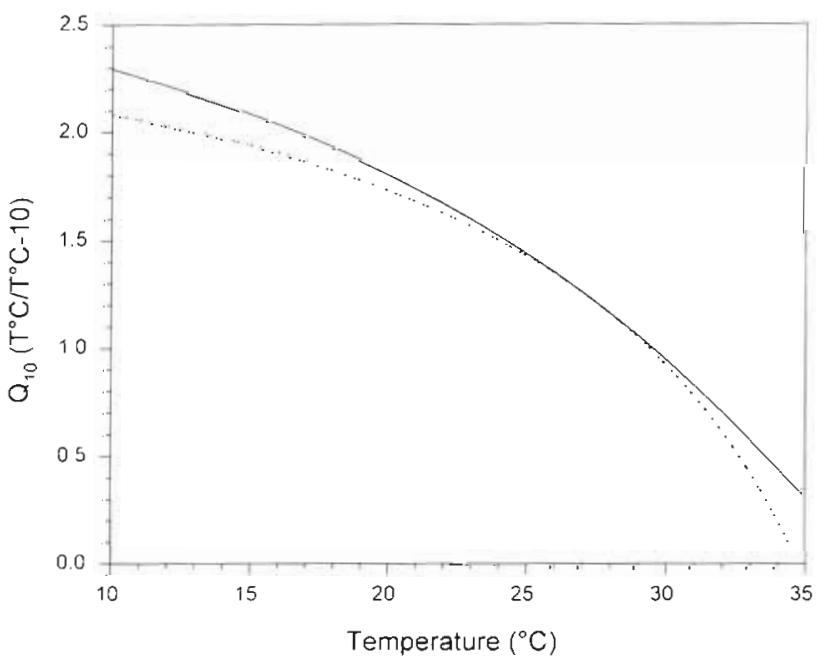

Fig. 3. $Q_{10}$ (between $T$ and $T-10$ ) calculated from the experimental data with interpolation. (-) September 1995; (‥) December 1995 thesis, so that it has to be taken into account in models of primary production and in field measurements in emersion conditions

The general model we propose describes the kinetic aspect of the relationship between $P_{\max }$ of microphytobenthos and temperature and can be used for both modelling and ecophysiological purposes.

Acknowledgements. We are very grateful to $\mathrm{M}$. Breret for performing chl a measurements. We also thank the Centre National de la Recherche Scientifique (INSU-DRV), the Institut Français de Recherche et d'Exploitation de la MER (DRV/RA) and the Région Poitou-Charentes for their financia] support.

\section{LITERATURE CITED}

Admiraal W (1977) Influence of light and temperature on the growth rate of estuarine benthic diatoms in culture. Mar Biol 39:1-9

Admiraal W, Peletier H (1980) Influence of seasonal variations of temperature and light on the growth rate of cultures and natural populations of intertidal diatoms. Mar Ecol Prog Ser 2:65-43

Arrigo KR, Sullivan CW (1992) The influence of salinity and temperature covariations on the photophysiological characteristics of Antarctic sea ice microalgae. J Phycol 28 $746-756$

Cadée GC. Hegeman J (1974) Primary production of the benthic microflora living on tidal flats in the Dutch Wadden Sea. Neth J Sea Res 8:260-291

Cariou-Le Gall V, Blanchard G (1995) Monthly HPLC measurements of pigment concentration from an intertidal muddy sediment of Marennes-Oléron Bay, France. Mar Ecol Prog Ser 121:171-179

Colijn F, de Jonge VN (1984) Primary production of microphytobenthos in the Ems-Dollard Estuary. Mar Ecol Prog Ser 14:185-196

Colijn F, van Buurt G (1975) Influence of light and temperature on the photosynthetic rate of marine benthic diatoms. Mar Biol 31:209-214

Couch CA (1989) Carbon and nitrogen stable isotopes of meiobenthos and their food resources. Estuar Coast Shelf Sci 28:433-441

Davison IR (1991) Environmental effects on algal photosynthesis: temperature. J Phycol 27:2-8

de Jonge VN, Colijn F (1994) Dynamics of microphytobenthos biomass in the Ems estuary. Mar Ecol Prog Ser 104 $185-196$

Efron B (1979) The 1977 Rietz lecture. Bootstrap methods: another look at the jackknife. Ann Statist 7:1,-26

Efron B (1988) Computer intensive methods in statistical regression. SIAM Rev 30:421-449

Eppley RW (1972) Temperature and phytoplankton growth in the sea. Fish Bull US 70:1063-1085

Grant J (1986) Sensitivity of benthic community respiration and primary production to changes in temperature and light. Mar Biol 90:299-306

Haardt $H_{1}$ Nielsen GAE (1980) Attenuation measurements of monochromatic light in marine sediments. Oceanol. Acta 3: $333-338$

Harrison SJ (1985) Heat exchanges in muddy intertidal sediments: Chichester Harbour, West Sussex, England. Estuar Coast Shelf Sci 20:477-490 
Harrison SJ, Phizacklea AP (1985) Seasonal changes in heat flux and heat storage in the intertudal mudflats of the Forth Estuary, Scotland. J Clim 5:473-485

Harrison SJ, Phizacklea AP (1987) Vertical temperature gradients in muddy intertidal sediments in the Forth estuary, Scotland. Limnol Oceanogr 32:954-963

Jorgensen BB, Des Marais DJ (1986) A simple fiber-optic microprobe for high resolution light measurements: application in marine sediment. Limnol Oceanogr 31:1376-1383

Lewis MR, Smith JC (1983) A small volume, short-incubationtime method for measurement of photosynthesis as a function of incident urradiance. Mar Ecol Prog Ser 13:99-102

Nelder VA, Mead R (1965) A simplex method for function minimization. Computer J 7:308-313

This note was submitted to the editor
Palmisano AC, SooHoo JB, Sullivan CW (1987) Effects of four environmental variables on photosynthesis-irradiance relationships in Antarctic sea-ice microalgae. Mar Biol 94 299-306

Parsons TR, Maita Y, Lalli CM (1984) A manual of chemical and biological methods for seawater analysis. Pergamon Press, Oxford

Raillard O, Menesguen A (1994) An ecosystem box model for estimating the carrying capacity of a micro-tidal shellfish system. Mar Ecol Prog Ser 115:117-130

Rasmussen MB, Henriksen K, Jensen A (1983) Possible causes of temporal fluctuations in primary production of the microphytobenthos in the Danish Wadden Sea. Mar Biol 73:109-114

Manuscript first received: January 25, 1996

Revised version accepted: March 15, 1996 